\title{
The Experience of Difference: Re-thinking the EDSA Revolution as an Exemplar of Ascending Life
}

\author{
Raniel Sta. Maria Reyes*
}

\section{Abstract}

Does talking about the triumph of the 1986 People Power EDSA Revolution still make sense nowadays? When the ideals of this glorious revolution are now nothing but contents of Philippine history textbooks and items of the culture industry, do we still need to re-imagine it? These are some of the reflective questions that will challenge and guide this paper's architecture. In what follows, the author will push all the possibilities for a Nietzschean rethinking of the EDSA Revolution as "the experience of difference and an exemplar of ascending life." In the first part, an account of the nature of EDSA revolution will be illustrated; while in the second, the principle of the 'Will to Power' and 'Eternal Return' will be explained using Gilles Deleuze's rhizomatic eyeglasses. In the third, the narrative of the revolution, i.e., the process on how the Epifanio Delos Santo Avenue (EDSA) turned into an arena for collective-political action will be delineated. Furthermore, the concept of difference will be utilized in explaining the dynamic occurrences produced by the Dionysian assemblage of Filipino bodies. In the last, the challenge of a different return of the said revolution will be explained.

*Department of Philosophy, University of Santo Tomas, Philippines 
"And what would eternal return be, if we forgot that it is a vertiginous movement endowed with a force: not one which causes the return of the same in general, but one which selects, one which expels as well as creates, destroys as well as produces?" (Gilles Deleuze, Difference and Repetition)

"The heaviest of burdens is an image of life's most intense fulfillment. The heavier the burden, the closer our lives come to the earth, the more real and truthful they become." (Milan Kundera, The Unbearable Lightness of Being)

\section{The EDSA Phenomenon}

Ferdinand Marcos' declaration of Martial law on September 21, 1972 was shaped by the looming social chaos and political resistance that plagued the Philippine society during his presidential reign. His dream of a so-called "New Philippine Society" geared to overcome the current status quo, was satirically prefaced by different forms of human rights violations, media blackouts, and constitution modification. This projected utopia was nonetheless a propagandist ploy to safeguard his delusion of infallible power. Accordingly, a distinctive brand of struggle was initiated by the people-the 1986 EDSA People Power Revolution.

The scorching animosity within the people's hearts during Marcos' rule was aggravated when his foremost critic Ninoy Aquino was assassinated upon his arrival at the airport, after coming from a three-year exile. Ninoy's assassination on August 21, 1983 obliterated the long silence of the Filipinos. Manifold mass demonstrations against the government followed after his death. Marcos then started to lose the support of the local and international community, thereby prompting him to call for a snap election in 1986. Consequently, due to the extensive irregularities in the election, Ninoy's wife Cory Aquino moved outside her existential shell, and fought for the presidency. Although she lost the political battle, Marcos' squalid victory easily melted into the air and became a volatile ground for the prevention of his downfall. 
The previously sporadic middle class, religious persons from different affiliations, and many ordinary citizens, then metamorphosized into a robust assemblage of affirmative forces, capable of dismantling a politico-transcendental center using means that surmount banal rationality. Significantly, the three-day revolution ended the dictatorship, and opened the Filipinos towards the state of re-evaluation about the many political and ethical principles revolving around the Philippine society. Despite different societal predicaments, they stood at the top of historical consciousness in promoting the importance of patriotism, nationalism, dignity, and life affirmation.

Before the vibrant nature of the said revolution is philosophically explored, it is necessary first to elucidate Nietzsche's formulations of the Will to Power and the Eternal Return that play a capillary role in relating the assemblage of forces present in this differential activity.

\section{The Will to Power and the Eternal Return}

Nietzsche's principle of the Will to Power is one of the most politically abused among his thoughts. It is misappropriated along the context of violent oppression of the weak by the strong or of the clamor for power. However, this ice-berg view overlooks the fecund ethics of life behind this principle.

Nietzsche defines life as characterized by the will to power. ${ }^{1} \mathrm{He}$ highlights the role of the will in a being a principle of affirmation. The value of the will to power is itself the value accorded to life-the only ontological reality we cannot deny. Furthermore, the Deleuzian understanding of the will to power attempts to salvage Nietzsche from the various paradoxes generated by his philosophizing. Whereas Nietzsche's formulation is a valiant effort to move away from western foundationalism, Deleuze's re-

\footnotetext{
${ }^{1}$ Friedrich Nietzsche, The Will to Power, trans. Walter Kaufmann and R. J. Hollingdale, New York: Vintage Books, 1967, §254, 92.
} 
formulation of the will to power is a radical activity which gives Nietzsche a more polysemeic and germane voice in the contemporary milieu.

Chiefly, the will to power is the differential character of force. To enliven this conceptualization, Deleuze explains that life forces and values are only secondary to the will to power. This principle consists of a confluence of forces still needing further engagement to other forces. For him, "the will to power is the element from which derive both the quantitative difference of related forces and the quality that devolves into each force in this relation. The will to power here reveals its nature as the principle of the synthesis of forces." 2 In other words, the will to power defines and delimits variations of forces.

The will to power's necessary addition to force is only possible because of the relational fuel of chance. In essence, chance is already immanent to this principle since it is the sole ethical principle that can affirm it. Moreover, the will to power identifies the dynamic appearance of forces. It interprets and evaluates by identifying a hierarchy (origins) of values between different forms of life on whether it will be active or reactive. It acts as the source of meaning and value due to its interpretative and evaluative capacity which is fundamentally creative, and does not aspire, seek, and desire power because it gives." 3 In other words, power entails abundance, and the will does not desire power, since it is already a manifestation of power.

Even before Nietzsche treated power within the context of the will, it was perennially a matter of feeling for him. In his words, "the will to power is the primitive affective form which all other feelings

2 Gilles Deleuze, Nietzsche and Philosophy, trans. Hugh Tomlinson, New York: Columbia University Press, 1983, 52.

3 Deleuze, Nietzsche and Philosophy, 97. 
derive. ${ }^{4}$ Furthermore, power in the will to power is the foundation of genealogical evaluations. For instance, "love" is not something to be comprehended based from any transcendental structure. Rather, it is created and expressed through the relation of immanent forces whereby the body acts as the substratum. Certainly, even "truth" is something fashioned in a plural manner because all becomings are determined by relation of material forces. ${ }^{5}$

After the death of God, life is given a chance to live anew naturally and vigorously. In performing what is life-affirming, Nietzsche formulates the typologies of the ascending and the descending life, and introduces the metaphor of the eternal return in order to test us on what kind of life do we want to recur.

Fundamentally, the eternal return is not the return of the Same. In comprehending this special principle, we must remember Nietzsche's radical anti-Platonist position in his intellectual thinking. Of course, Plato's adherence to the principle of being is perceived by him as exploitive to life's vitality. On the contrary, he renders becoming with highest affirmation. According to Deleuze, the eternal return is not a return of being and the Same, but of becoming and difference, the world of Heraclitus and chance. ${ }^{6}$ In Thus Spoke Zarathustra, Nietzsche, likewise, explains that living in this chaosmos is, "playing dice with gods at the god's table, the earth."7 The dice-playing world is the garden for the child and the machinery capable of producing both good and bad dice-players.

4 Nietzsche, The Will to Power, §103, 42.

5 Nietzsche, The Will to Power, 299.

6 Ronald Bogue, Deleuze and Guattari, New York: Routledge, 1989, 29.

7 Friedrich Nietzsche, Thus Spoke Zarathustra: A Book For Everyone and No One, "The Seven Seals," trans. R.J. Hollingdale, London: Penguin Books, 1969, III, 341. 
Indeed, the will to power is the synthesis and determining principle not only of differential element of forces, but also of the eternal return. The eternal return's ability of affirming difference is tantamount to the affirmation of becoming. This ardent activity constitutes the physical typology of the eternal return. It is parallel to its ethical aspect, which portrays the rhizomatic narrative on how we can overcome the mediocrity towards the ascending affirmation of the will to power.

As values are not anymore grounded on a transcendental plane, they are rather founded on how we view life and expend our potentialities. In this vein, the value of life depends on whether we are going to recognize it as ascending or descending. The manner of how we value life is identified by the value of power that we expend. For this reason, power becomes a conditio-sine-qua-non for directing our life.

To further expound his ethical typologies, Nietzsche used Christianity as a model (symptom) of decadence so as to contrast it with ascending life, and to elucidate the phenomenon of nihilism prevalent in modern culture. Christian morality being the bastion of herd instinct is a form of slave revolt, which causes our negative view of life. The slaves are those who believe in traditional fictions, like: the belief for the second-coming and the one-dimensional view of self-preservation and negation of all master-related values. In the descending pathway, life as will to power is denied and its essential forces do not experience becoming-other.

However, we must not forget that man, as Zarathustra conceives, is a transition-he must be overcome. As such, we must not focus on the negative consequences of God's death, for the pre-condition of living an ascending life is by de-deifying nature or annihilating even God's shadows. ${ }^{8}$ This is the content of Nietzsche's ethics and ontology of affirmation. An ethics of affirmation is the intricate challenge of becoming active, and of practicing pathos of distance. York: Vintage, 1974, 109. 
Lastly, the will to power, albeit incessantly challenged by the will to nothingness of ressentiment, is a vital force of life. Its Deleuzian appropriation optimizes differential planes of affirmation and negation that process the understanding of the active and reactive forces viz. the ascending and descending life. It is a principle which genealogically operates within the planes of qualitative and quantitative differences between life forces. Along this line of reasoning, the will to power transforms into a form of desire. It is a desire beyond its traditional usage, which is open for a creative play with power, thereby making desire a productive force. Ultimately, the will to power is a functionalist form of desire that escapes reification and that renders life into a multiplicity of becomings and a plethora of relational assemblages.

\section{Immanent Revolution, Bodies, and Dice-throwing}

\section{a) Assemblage of Bodies and Forces}

During the revolutionary struggle, the quantity of the Filipino bodies, as days passed increased. The Church called the people to express their basic human rights. Coming from different religious orientations and social status, they congregated themselves to face the military machinery, fearless of the harm that could happen anytime. The Filipinos flooded the EDSA road to exhilarate and experience difference, which at time was understood under the term democracy.

The political and ethical rationality behind the revolution caused the overcoming of Apollonian social frameworks via the Dionysian principle. ${ }^{9}$ For Nietzsche, the Dionysian is an experience of

The Dionysian is contextualized in Critical History, where the Dionysian is that which dissolves the Apollonian, implying that all things in this world are provisional and re-convertible: "Every past, however, is worth condemning." See Friedrich Nietzsche, The Birth of Tragedy, New York: Dover Publications, Inc., 1995, 21. Critical history is the Dionysian purposeful forgetfulness of portions of the past, so as to preserve life. This implies a process of renewal, of reformulation. 
intoxication that effectuates the principium individuationis to its annihilation and "which everything subjective vanishes into complete self-forgetfulness." 10 In this context, the Dionysian pertains to the merging of formerly individuated Filipino bodies and disjointed forces. In The Birth of Tragedy, Nietzsche argues:

Under the charm of the Dionysian, not only is the union between man and man re-affirmed, but Nature, which has become estranged, or subjugated, celebrates once more, her reconciliation with her prodigal son, man [...] Now all the stubborn, hostile barriers, which necessity, caprice have erected between man and man, are broken down. Now, each one feels not only united, reconciled, blended, with his neighbor, but as one with man."11

Similarly, in the Thus Spoke Zarathustra, the Dionysian is luminously realized in Zarathustra's activity of down-going. Primarily, down-going for Nietzsche, signifies immersion with the people in the community along with interconnected forces, hence freeing oneself from the cage of individuality and proliferating flourishing. As a corollary, Hannah Arendt's theorization of power runs convergent to this explication on the ground that the power during this event depicted array of bodies in dynamic movements. It is converted into something which paved for the cultivation of mobile bodies. In Arendt's words, "Power is never the property of an individual; it belongs to a group and remains in existence only so long as the group keeps together." 12 The collective power fashioned in the revolution personified into bodies without organs in being immersed with the Dionysian current. The EDSA highway turned into an arena for the will to power's expression-a stage for the aesthetic relation of forces and performance of different bodies coming from facets of life. The struggle between reactive and active

10 Nietzsche, The Birth of Tragedy, §1, 3 .

11 Nietzsche, The Birth of Tragedy, 4.

12 Hannah Arendt, On Violence, San Diego: Harcour, 1976, 44. 
forces around the place characterized the typology of liquid bodies amassing the public space. In Nietzsche and Philosophy, Deleuze argues that a body is defined by the relationship between antagonistic forces:

Every relation of forces constitutes a body-whether it is chemical, biological, or political [...]. Being composed of a plurality of irreducible forces, the body is a multiple phenomenon; its unity is that of a multiple phenomenon. In a body, the superior or dominant are known as active and the inferior or dominated are known as reactive. ${ }^{13}$

The will to power as a determining principle for the relation of forces and bodies, has the aptitude of affectivity. This idea was observed by Deleuze as significantly closed to Spinoza's belief that the force of the body is a function of the number of ways in which it can be affected and that a body's capacity for being affected is an expression of its power. ${ }^{14}$ In Nietzsche's and Spinoza's critical eyes, the body's capability of being affected is not tantamount to passivity, but to moral sensitivity and genuine goodness spawned by the singularity of the revolutionary moment.

Amidst the event's embeddedness in the realm of flux, we must be incessantly heedful about the inherent dogmatic tendency of political power because it is really mortifying to life. When power is viewed using the Heraclitean lens, it will protect a particular leader from being estranged to the reifying illusions surrounding it.

Power is an assemblage of individuals which prohibits itself to be expressed in densely Apollonian epistemology, for the evasion of its oppressive mutation. In this vein, looking for a particular individual behind this revolutionary ardor is a futile venture,

13 Deleuze, Nietzsche and Philosophy, 40.

14 Bogue, Deleuze and Guattari, 23. 
because the groundwork of this force is becoming and doing. When the concept of the individual is de-centered, the possibility of political opportunism and future tyranny can be seized upon. This is differential power at its best, emanating not from a transcendental center, but from a consolidation of social forces. On this account, the EDSA revolution can be strappingly pondered as a communicative activity that addled the voices of some narcissistic personalities or leaders, thereby elevating the status of the highspirited bodies moving in differential fashion.

In addition, power as a collective dance can only be best illustrated when participated by anonymous bodies. According to one of the Filipino participants:

Watching them, listening to them, feeling them, I suddenly realize that these millions have already transcended Cory, Enrile-Ramos, and Marcos. Cory, Enrile-Ramos and Marcos have, in fact, become incidental to the situation. ${ }^{15}$

Since the political participants in the revolution were in a uniquely exigent singularity, novel codes of interaction and resistance were forged. Definitely, this experience of non-thematizable collectivity became an artwork on its own.

\section{b) A Differential Filipino Response to the Same}

During the Marcos' totalitarian regime, the emancipatory spaces for human potentialities were drastically repressed. Like Christianity, his government typified the deficiency of a metaphysical guarantor to regulate the Filipino bodies' passage towards ascending life, and the inability of its system to endorse and value the provisional and material features of life. When the Filipino existential situation was

15 Mercado, Monina, and Tatad, Francisco, People Power: The Philippine Revolution of 1986: An Eyewitness History, Manila: The James Reuter, S.J. Foundations, 1986, 238. 
already feebly administered and oppressed by the autocratic machinery, the very possibility of an architectural structure to gain a promethean might was conditioned.

The ubiquitous change of social landscape during the revolution was never totally eradicated, but was harmoniously re-attuned for the people's higher glory-a sheer portrayal of the Nietzschean adage of experiencing chaos to become a dancing star. ${ }^{16}$ Foregrounded in the exceptional character of the revolution, anonymous individuals/bodies became awed by the novelty of the event and to its consequential gravity. ${ }^{17}$ An ethical test dawned in front of the people's perception either to overcome decadence or to remain within the confines of herd morality. In Nietzschean terms, this is an extraordinary moment to choose either ascending or descending life typology. On the other hand, to make it more radically Deleuzian, the aforesaid event converted into a chaotic canvass where "divergence is affirmed in such a way that the either ... or itself becomes a pure affirmation [...]. Thus, the ideational center of convergence is by nature perpetually de-centered, it serves only to affirm divergence." 18

Outside the $A B C^{\prime} s$ of past revolutions and notions of political change, bodies, values, and language configurations were transformed. Since various Filipino bodies were not yet fully penetrated by political ideologies (shadows of reactive values) at that time, the participants compellingly immersed themselves with the macro-struggle, even though their body physiology is not oriented for a revolution. The paramount and roaring arrival of

16 Nietzsche, Thus Spoke Zarathustra, I, Prologue, 5.

17 Fernando Gonzaga, "People Power as Immanent Collectivity: Reimagining the Miracle of the 1986 EDSA Revolution as Divine Justice," in New Scholars Forum (Kritika Kultura) 12 (2009), 117.

18 Gilles Deleuze, Logic of Sense, trans. Mark Lester, New York: Columbia University Press, 1990, 174. 
difference devoured metaphysico-epistemological frameworks and relations.

The non-violent radicalization of performances was construed by the spontaneity of the moment. The struggle's bloodless face was rationally astonishing. Due to the dejected experience of the people under the Marcos regime, many individuals had even brought weaponries with them for contingency purposes. This entailed that violence could happen at any moment. However, due to the spirit of difference, the 1986 EDSA revolutionaries gallantly went to the streets to unify their bodies unify under a shared principle amidst the threat of the government's iron hand. The differential force of the revolution opened them towards a path for life-affirmation. This experience of the "new" surmounts the linear topography of previous revolutions, politically and ethically. Hence, the revolution was really a lofty event incomparable to the past and understandable on its own terms as a time of significant ethical confrontations.

In being pacified and anti-deterministic, its call for increased collective spirit was based on pragmatic grounds, and not from any foundational source. Even the forefront of the dictatorial machinery (the soldiers), who are the closest to the meta-center's structurality had a difficulty in avoiding the dice-playing ardor of the struggle. In short, the EDSA revolution paved the transgression of violence, individuality, traditional history, revolution, and more importantly, values. The assemblage of all these material forces ruptured the limiting boundaries of social order. Lastly, the revolution, happening only in the world of appearance, brought as back to Nietzsche's theorization of the world as chaotic, and ateleological, in characters.

Another foremost attribute of will to power's determining activity, as argued earlier, is its differential element of forces. The experience of the non-thematizable creativity made the EDSA an artistic example of the affirmation of chance: 
Uncertain of its outcome, the people vacillated between the different affective responses. On the one hand, the event was incomprehensible, because the series of episodes that transpired and the eventual outcome that it produced appeared to be accidental. ${ }^{19}$

This people power revolution concretized only when compound Filipino bodies were spontaneously called forth to assemble at EDSA to strongly bridge chaos and the world. The assemblage of forces which converted into an immense potency necessitated still the presence of the will to power as something which overcomes them, but is necessary for them for their own actuality. ${ }^{20}$ The numerous molecular singularities that occupied the public space like the non-violent overthrow of a political center were completely subjected in the logic of chance. Brilliantly, the ground-breaking throw of the revolutionary dice is the ardent risk for the affirmation of chance, which eventually spawned the opening of the world and the Filipino bodies to the multiplicity of possibilities.

The festivity of its success did not exist from an immediate molar picture, for it was derived from previously fragmented occurrences. You could see civilians becoming authentic participants in the politico-artistic performance and women transcending their patriarchal gender constitutions by serving all they can just to give meager help to the participants, including the government's soldiers. To some extent, even nature coalesced with this ethical rampage. Take for instance, a tear gas which was supposed to help scatter the mob during a grand military assault, was blown by the wind back in the direction of the troops. In addition, the helicopters flew over the camps, the Filipinos were

19 Gonzaga, "People Power as Immanent Collectivity: Re-imagining the Miracle of the 1986 EDSA Revolution as Divine Justice,"124

20 Deleuze, Nietzsche and Philosophy, 54 
expecting rocket firings toward their direction, but they landed instead, their pilots defecting to the rebel forces. ${ }^{21}$

Astonishingly, the EDSA revolution went beyond the grain of political and ethical struggle. The assemblage of bodies was characterized by the 'dice-throw' principle with its spontaneity, dynamicity, immanence, and openness. The multiplicity of becomings inherent in the collective force of affirmative bodies depicted in EDSA was fashioned by the Nietzschean moment of will to power and chance. According to Deleuze:

The will to power as a principle does not suppress chance, but implies it, because without chance it would be neither plastic nor changing. Chance is the bringing of forces into relation, the will to power is the determining principle of this relation. The will to power is a necessary addition to force but can only be added to forces brought into relation by chance. The will to power has chance as its heart for only the will to power is capable of affirming all chance. ${ }^{22}$

After injustice's mutation in all its possible faces in the Philippine soil, which converted EDSA into a degenerative social space, the diversely internal and negative experiences of the people had actualized into a huge ethical force desiring for Heraclitean "eternal justice". Here, even the etymology of the word "justice" explodes, towards the new grounds of immanence and becoming. The people's will to power, manifested in the arrival of the unexpected obliterated everything metaphysical and regimented. In this wondrous singularity, differential justice embraced material reality like a Dionysian dynamite fashioning the realization of new values: "It really felt like a miracle was happening. Soldiers not firing even when ordered to, my own children and wife in EDSA were actually

21 Gonzaga, "People Power as Immanent Collectivity: Re-imagining the Miracle of the 1986 EDSA Revolution as Divine Justice," 124. 
enjoying it, and the weather so nice and cool throughout the few days. ${ }^{23}$

During the revolution, the despotic center radicalized from being to becoming. The noise of every manifestation of dejected experiences, like frustrations and inequalities, turned into music; the formerly complex and risky movements of bodies became a joyful dance; and, life became a meaningful celebration.

\section{The Challenge of the Return and the New Enemy}

If the principle of difference is affirmatively activated from within the body of a revolution or any affects, it would condition the very possibility of radically meaningful events. In the context of the EDSA revolution, we saw a landscape to which immanent means demolished a totalitarian normativity. This singularity renders reality into manifold transfigurations, which opened the gates for Filipinos in furthering a descending or ascending life typology. When this event again recurs, the challenge is whether we will be in the side of Silenus (reactive force) or Oedipus (active).

The inevitable propensity of the mind to freeze experience tempts us to fashion stable concepts to compensate for the absence of coherent epistemologies that would serve as our eyeglasses. However, based from the lessons given to us by history, when the provisional attribute of any concept is marginalized in favor of the principle of being, then this EDSA gift can be converted instead into several forms of mediocre values and subjugation. To be more specific, this was portrayed when the EDSA revolution paradoxically returned under the reified label of EDSA II and III. To two EDSA's may run parallel to the first probably on superficial status due to mass media's trivialization. On the philosophical

23 Mercado, Monina, and Tatad, Francisco, People Power: The Philippine Revolution of 1986: An Eyewitness History, Manila: The James Reuter, S.J. Foundations, 1986, 250. 
plane, its legitimacy can be rationally accepted as a return founded on slavish politics, originating from another dictatorial power with a different face.

Since our country is presently totalized by global hegemony, decayed ideologies, and pseudo-leaders, hoping for a return of something like the first EDSA appears to be an anti-Nietzschean dream, for initially what returns in the eternal return is not the Same. ${ }^{24}$ In fact, an active destruction of memory can elicit profound creativity for Nietzsche. To make his philosophy more explosive, the EDSA revolution itself must not escape radicalization. When we exceedingly monumentalize this historical alterity, then memory will develop into a work of ressentiment; that is why a Dionysian forgetting must always be within integral grasp, for this would require selection and affirmation of difference.

Many things about the Philippine society have now developed belligerently. Even the concept of ascending life is systemically bastardized by the culture industry today via the proliferation of one-dimensionality-the contemporary word for reactive life. In this manner, the question on what kind of life do we want to recur is something extremely alien to the Filipino everyday for our critical acuity and the whole landscape of human interrelations are presently corrupted by capitalism and decadence. Doubtless, another Nietzschean revaluation is very ripe in the Philippine society. However, our new adversary has paradoxically selfevolved, i.e., in gaining a human face characterized by malleable centers. For this reason, an innovative kind of revolutionary resistance must be formulated-faithful to the Deleuzian definition of philosophy as the creation of novel concepts. With the

24 For Deleuze, "The eternal return is not the effect of the Identical upon a world becomes similar, it is not an external order imposed upon the chaos of the world; on the contrary, the eternal return is the internal identity of the world and of chaos, the Chaosmos." See Deleuze, Difference and Repetition, trans. P. Patton, New York: Columbia University Press, 1994, 299. 
provisional spirit of everything, Nietzsche's principle of difference must be transformed into Adorno's non-identical, 25 for more epistemological expansion and socio-political breadth.

In the dice-playing world of chance, the next EDSA can originate from either a reactive or active premise. ${ }^{26}$ The hope remains that it would be derived from an affirmative ethics of recognition whose internal fuel is the will to power-the will to ascending life. But since life has a Janus face, we must unendingly be critical about the idea that the very space of human flourishing can be the similar site for debasement.

If the EDSA singularity returns, it will be of a different life force. If a diverse event recurs, the perennial crucial question is whether we, as molecular assemblages, are ready to say YES to the world of chance? No matter how many EDSA's will come along our way, if we Filipinos will not learn active life 101, our lives will be an incessant recurrence of nihilism. The return of the different can bear a different name from a different place, and can happen with a different magnitude. Considerably, it can also come from distant local communities far from mainstream political centers, whose inhabitants wear different shades of eye-glasses or to any phenomenological location such as from ourselves. However, despite all of these, the dynamic attribute of experience and the loving struggle for the ethics of life must always be at hand.

Indubitably, the 1986 EDSA People Power Revolution is an exemplar of an Ascending Life, the Filipino way. It is a culture of

25 The "non-identical" is the guiding thread of Theodor Adorno's philosophy. This concept recoils from subsumption under universal concepts and traditional norms. Moreover, it can never be completely appropriated by any universal description, since it can always be newly described. This radical philosophy was conceptualized by him to embattle the metaphysical domination of identity thinking or instrumental reason in modernity. See Theodor Adorno, Negative Dialectics, trans. E. B. Ashton, London: Routledge, 1973, 143.

26 The eternal return, being a selective principle, can be the return of the negative or the affirmative. However, for Deleuze, the principle itself would transform into contradiction when it becomes a return of reactive forces. See Deleuze, Difference and Repetition, 200. 
marvelous affirmation of difference, which is the chaotic multiplicity of the world's becoming.

\section{References}

Adorno, Theodor, Negative Dialectics, trans. E. B. Ashton, London: Routledge, 1973.

Allison, David B., ed., The New Nietzsche: Contemporary Styles of Interpretation, New York: A Delta Original, 1977.

Ansell-Pearson, Keith, An Introduction to Nietzsche as Political Thinker, Cambridge: Cambridge University Press, 1994.

Arendt, Hannah, On Violence, San Diego: Harcour, 1976.

Bogue, Ronald, Deleuze and Guattari, New York: Routledge, 1989.

Conway, Daniel, Nietzsche and the Political, London: Routledge, 1997.

Deleuze, Gilles and Felix Guattari, What is Philosophy?, trans. Hugh Tomlinson and Graham Burchell, New York: Columbia University Press, 1994.

Deleuze, Gilles, Difference \& Repetition, trans. Paul Patton, New York: Columbia University Press, 1994.

Deleuze, Gilles, Nietzsche and Philosophy, trans. Hugh Tomlinson, New York: Columbia University Press, 1983.

Deleuze, Gilles, The Logic of Sense, trans. Mark Lester, New York: Columbia University Press, 1990.

Gillespie, Michael and Strong, Tracy, eds. Nietzsche's New Seas: Explorations in Philosophy, Aesthetics, and Politics, Chicago: University of Chicago Press, 1988.

Gonzaga, Fernando, "People Power as Immanent Collectivity: Reimagining the Miracle of the 1986 EDSA Revolution as Divine Justice," in New Scholars Forum (Kritika Kultura) 12 (2009), 109-127.

Gooding-Williams, Robert, Zarathustra's Dionysian Modernism, Stanford: Stanford University Press, 2001.

Hatab, Lawrence, A Nietzschean Defense of Democracy: An Experiment in Postmodern Politics, Chicago: Open Court Publishing Co., 1995.

Heilke, Thomas, Nietzsche's Tragic Regime, Dekalb: Northern Illinois University Press, 1998. 
Kaufmann, Walter, Nietzsche: Philosopher, Psychologist, Antichrist, Fourth Edition, Princeton: Princeton University Press, 1974.

Lamothe, Kimerer, Nietzsche's Dancers, New York: Palgrave MacMillan, 2006.

Magnus, Bernd and Higgins, Kathleen, eds. The Cambridge Companion to Nietzsche, Cambridge: Cambridge University Press, 1996.

Mercado, Monina, and Tatad, Francisco, People Power: The Philippine Revolution of 1986: An Eyewitness History, Manila: The James Reuter, S.J. Foundations, 1986.

Nietzsche, F., Beyond Good and Evil: Prelude to a Philosophy of the Future, trans. Walter Kaufmann, New York: Vintage, 1966.

Nietzsche, F., Human, All Too Human: A Book for Free Spirits, trans. R.J. Hollingdale, Cambridge: Cambridge University Press, 1986.

Nietzsche, F., On the Advantages and Disadvantages of History for Life, trans. Peter Preuss, Indianapolis: Hacket Publishing Co., 1980.

Nietzsche, F., On the Genealogy of Morals, trans. Walter Kaufmann, in Basic Writings of Nietzsche, New York: Modern Library, 2000.

Nietzsche, F., Philosophy in the Tragic Age of the Greeks, trans. Marianne Cowan, Indiana: Gateway, 1962.

Nietzsche, F., The Birth of Tragedy, New York: Dover Publications, Inc., 1995.

Nietzsche, F., The Gay Science, trans. Walter Kaufmann, New York: Random House, Inc., 1974.

Nietzsche, F., The Will to Power, trans. Walter Kaufmann and R. J. Hollingdale, New York: Vintage Books, 1982.

Nietzsche, F., Thus Spoke Zarathustra: A Book For Everyone and No One, trans. R.J. Hollingdale, London: Penguin Books, 1969.

Nietzsche, F., Writings from the Late Notebooks, trans. Kate Sturge, Cambridge: Cambridge University Press, 2003.

Pearson, Keith Ansell, Nietzsche as a Political Thinker, New York: Cambridge University Press, 1994.

Reginster, Bernard, The Affirmation of Life: Nietzsche on Overcoming Nihilism, Harvard University Press: Cambridge, 2006.

Schacht, Richard, Nietzsche, London: Routledge and Kegan Paul, 1983. 
Smith, Gregory \& Smith, Bruce, Nietzsche, Heidegger and the Transition to Postmodernity, Chicago: University of Chicago Press: Chicago, 1996.

Strong, Tracy, Friedrich Nietzsche and the Politics of Transfiguration, Berkeley: University of California Press, 1975.

Warren, Mark, Nietzsche and Political Thought, Cambridge: MIT Press, 1988. 